\title{
Community Small Onion / Multiplier Onion (Allium cepa var aggregatum) Nursery as a Contingency Measure for Delayed Planting in NICRA Village of Namakkal District, Tamil Nadu, India
}

\author{
C. Sharmila Bharathi ${ }^{1 *}$ and B. Mohan $^{2}$ \\ ${ }^{1}$ Krishi Vigyan Kendra, Tamil Nadu Veterinary and Animal Sciences University, \\ Namakkal, Tamil Nadu -637 002, India \\ ${ }^{2}$ Department of Animal Nutrition, Veterinary College and Research Institute, TANUVAS, \\ Orathanadu, Thanjavur-614625, India \\ *Corresponding author
}

\section{A B S T R A C T}

Vadavathur in Namakkal District is a drought prone village. The annual rainfall is 400 $\mathrm{mm}$. In Vadavathur village, small onion is cultivated in two main seasons viz., Early kharif (May - August) and Rabi (November - December). Generally small onion is propagated by means of bulbs. However, NICRA village Vadavathur experienced aberrant rainfall

Keywords

Community

Nursery, Small

onion, NICRA

village

Article Info

Accepted:

16 February 2018

Available Online:

10 March 2018 situations with minimum rainy days for the past 5 years during sowing season especially during Rabi impacting adversely small onion production and livelihood of farmers. It appears that failure of rain and prolonged dry spells in November - December is responsible, as sowing of small onion is delayed with resultant adverse affect on productivity. Delay in sowing of small onion affects productivity in terms of delayed sprouting, slow growth of vegetative phase and reduction in yield. To mitigate these problems, KVK, Namakkal established staggered community small onion var. Co (On) 5 nursery during October in an area of 0.4 ha covering 20 farmers as a local adaptation strategy at the village level to combat the problem experienced by farmers during deficit rainfall seasons. Majority of the farmers could take up transplanting using seedlings from the $1^{\text {st }}$ and $2^{\text {nd }}$ nursery raised on $1^{\text {st }}$ and $15^{\text {th }}$ October. Highest bulb yield of $77 \mathrm{gm} / \mathrm{plant}$, 22.3 tonnes /ha and benefit cost ratio of 3.4 was obtained by transplanting of onion seedlings which coincides with rainy days during November when compared to bulbs directly sown during December.

\section{Introduction}

Small onion / Multiplier onion, Allium cepa var.aggregatum $\mathrm{L}$ is one of the most important commercial vegetable and spice crops. The area under multiplier onion is being increased in India especially in Tamil
Nadu. The total area under onion in Tamil Nadu is 4.01 lakh hectares with a production of 47.27 lakh tonnes (Anon 2014). The study area of Vadavathur village, Erumapatti block, Namakkal District, Tamil Nadu is a drought prone village. The annual rainfall is $400 \mathrm{~mm}$; hence this village was selected to implement 
the National Initiative on Climate Resilient Agriculture (NICRA) Project during the year 2010. The main climatic vulnerability faced by NICRA farmers is drought. The total area and productivity of small onion under Namakkal district was 1,997 ha and $12 \mathrm{t} / \mathrm{ha}$, respectively. In Vadavathur village, small onion is cultivated in two main seasons viz., Early kharif (May -August) and Rabi (November - December) in an area of 425 ha. However, NICRA village Vadavathur experienced aberrant rainfall situations with minimum rainy days for the past 5 years during sowing season especially during Rabi impacting adversely small onion production and livelihood of farmers. It appears that failure of rain and prolonged dry spells in November - December, as sowing of small onion is delayed which resultant adverse affect on productivity. Delay in sowing of small onion affects productivity in terms of delayed sprouting, slow growth of vegetative phase and reduction in yield. The existing practice has led to use of high seed rate (Totally $12.5-15.0 \mathrm{q}$ of seed bulb is required for small onion cultivation in an area of 1 hectare), high cost involved for seed purpose (Rs. 25000 - 30,000 / ha) and also timely sowing during rainy season due to deficit rainfall. To mitigate these problems, farmers' preferred low seed rate variety which withstand drought during bulbing stage, ready availability of seedlings for transplanting at the time of rainy period to establish quickly with minimum rains is overwhelming and often wait for transplanting in rainfed areas till end of December in anticipation of rains.

Krishi Vigyan Kendra, Namakkal has introduced seed propagated small onion variety $\mathrm{Co}(\mathrm{On}) 5$. CO (On) 5 was developed by Tamil Nadu Agricultural University (TNAU), Coimbatore. It is a high yielding variety developed by mass pedigree method of selection. This variety has the ability of free flowering and seed set throughout Tamil
Nadu. It possesses high bulb yield 18.9 t/ha (18.8 per cent higher than $\mathrm{CO} 4$ ) in a crop duration of 90 days. It is free flowering type with seed setting ability of $250-300 \mathrm{~kg} / \mathrm{ha}$ and so it is propagated through seeds (Saraswathi et al., 2017). The seed rate required is $2.5 \mathrm{~kg} /$ ha. The objective of the study was to reduce risk in small onion cultivation during drought period by establishing community nursery in a staggered manner.

\section{Materials and Methods}

\section{Brief description about NICRA village}

The demonstrations were carried out at twenty famers' field of Vadavathur village of Namakkal District of Tamil Nadu during Rabi season 2013 -14, $2014-15$ and 2015 -16. In this village small onion is cultivated in an area of 425 ha. Vadavathur is situated at $11.9241^{\circ} \mathrm{N}$ latitude and $78.11917^{\circ} \mathrm{E}$ longitudes and at an elevation of $531 \mathrm{~m}$ above mean sea level. Based on 20 years weather data, it received an average rainfall of 400 $\mathrm{mm}$ annually, spreading over an average of 32 days in a year. The soil type is red sandy loam with a $\mathrm{pH}$ of 7.9 and $\mathrm{EC}$ of $0.064 \mathrm{dSm}^{-1}$ with a soil nutrient status of low Nitrogen $(188 \mathrm{~kg} /$ ha), medium Phosphorus (11 kg / ha) and high Potassium (294 kg /ha).

\section{Existing practice}

In Vadavathur village, small onion is cultivated in two main seasons viz., Early kharif (May -August) and Rabi (November December). The kharif crop is mainly used for seed purpose for raising next crop whereas the Rabi crop was used for vegetable purpose. $\mathrm{CO} 4$ and Valayapatti local is the predominant variety cultivated at Vadavathur. Generally small onion is propagated by means of bulbs. However, NICRA village Vadavathur experienced aberrant rainfall situations (Table 1; Fig. 1 and 2) with minimum rainy days 
(Fig. 3) for the past 5 years during sowing season especially during Rabi $(95 \mathrm{~mm}$ in 2011, $2 \mathrm{~mm}$ in 2012, $61 \mathrm{~mm}$ in 2013, $69 \mathrm{~mm}$ in 2014 and $100.5 \mathrm{~mm}$ in 2015) impacting adversely small onion production and livelihood of farmers. It appears that failure of rain (9 rainy days in 2011, no rainy days in 2012, 5 rainy days in 2013, 7 rainy days in 2014 and 8 rainy days in 2015) and prolonged dry spells (Table 2, Fig. 4) in November December (41 days in 2011, 61 days in 2012, 36 days in 2013, 45 days in 2014 and 33 days in 2015) is responsible, as sowing of small onion is delayed with resultant adverse affect on productivity.

Delay in sowing of small onion affects productivity in terms of delayed sprouting, slow growth of vegetative phase and reduction in yield. The existing practice has led to use of high seed rate (Totally 12.5 $15.0 \mathrm{q}$ of medium sized seed bulb is required for small onion cultivation in an area of 1 hectare), high cost involved for seed purpose (Rs. $25000-30,000 /$ ha) and also timely sowing during rainy season due to deficit rainfall. To mitigate these problems, farmers' preferred low seed rate varieties which withstand drought during bulbing stage, ready availability of seedlings for transplanting at the time of rainy period to establish quickly with minimum rains is overwhelming and often wait for transplanting in rainfed areas till end of December in anticipation of rains.

\section{Resilient practice/Technology intervention by KVK, Namakkal}

\section{Establishment of community small onion nursery}

Establishing a staggered community small onion var. Co (On) 5 nurseries was explored as a local adaptation strategy at the village level to combat the problem experienced by farmers during deficit rainfall seasons. The technique involves raising a staggered community nursery under assured irrigation in the village at an interval of 2 weeks. In the anticipation of a two weeks delay in monsoon the first nursery is taken up as a contingency measure with low seed rate $(2.5 \mathrm{~kg} / \mathrm{ha})$ variety $\mathrm{Co}(\mathrm{On}) 5$ by $1^{\text {st }}$ October in order to transplant 40 days old seedlings by first fortnight of November. If the monsoon delay extends by 4 weeks, the second nursery is raised by $15^{\text {th }}$ October to supply 40 days old seedlings for transplanting in the $3 \mathrm{rd}$ or $4^{\text {th }}$ week of November. In case of anticipation of further delay or deficit rainfall conditions, the 3rd nursery is raised by $1^{\text {st }}$ week of November to take up transplanting during first fortnight of December. The experiment was laid out in Randomized Block Design (RBD) with three replications at NICRA village of Namakkal District.

\section{Nursery management of small onion variety. Co (On) 5}

Raised bed nursery was formed with a size of $70-75 \mathrm{~cm}$ breadth, $15 \mathrm{~cm}$ height and $3-5 \mathrm{~m}$ length during first week of October 2014. Totally one cent area was required to raise seedling for one hectare. Well decomposed farmyard manure @ $10 \mathrm{~kg} / \mathrm{sq} . \mathrm{m}$ and $1 \mathrm{~kg}$ neem cake was applied to the nursery bed after the removal of stones and weeds. Seeds were treated with $4 \mathrm{~g}$ of Trichoderma viride and $10 \mathrm{~g}$ of Pseudomonas fluorescence 12 hours before sowing to prevent the seed borne diseases viz., basal rot and damping off.

Treated seeds were sown in line with $1 \mathrm{~cm}$ depth formed at $5 \mathrm{~cm}$ interval on the raised bed and was mulched with coconut fronds / paddy straw, which was used to maintain the temperature and moisture required for onion seed germination. Irrigation was given through rose can after mulching and was done daily up to 40 days after sowing. The seeds germinated five days after sowing, thereafter 
the mulch material was removed. Five days after germination, Trichoderma viride @ 100 gm was applied along with $25 \mathrm{~kg}$ of farm yard manure per nursery bed to prevent the damping of disease in seedling stage. Hand weeding was done at 10 days interval. Forty days after sowing, the seedlings were pulled out from nursery bed for transplanting.

\section{Transplanting of seedlings}

Irrigation was applied one day prior to transplanting. Forty days old healthy seedlings (Table 3) of aggregatum onion cv. Co $(\mathrm{On}) 5$ were transplanted in the flat beds at a distance of $15 \times 10 \mathrm{~cm}$ during $1^{\text {st }}$ fortnight of November (Table 3). Fifteen days before transplanting, $100 \mathrm{~kg}$ of well powdered and decomposed farmyard manure enriched with each one $\mathrm{kg}$ of Trichoderma viride and Pseudomonas fluorescence was applied to prevent basal rot in the field. At the time of transplanting $65 \mathrm{~kg}$ of urea, $375 \mathrm{~kg}$ of super phosphate and $50 \mathrm{~kg}$ of potash was applied as a basal manuring per ha area. Five days after transplanting, maize as a barrier crop (NK 6240) was sown around the field and ridges at a spacing of $1 \mathrm{ft}$, to prevent the entry of thrips from the neighbouring fields. Thereafter, blue sticky traps were installed at $100 \mathrm{~m}$ interval with a total of 50 traps/ ha at one $\mathrm{ft}$ height above the onion plant to attract the thrips.

Top dressing of $65 \mathrm{~kg}$ of urea and $50 \mathrm{~kg}$ of potash was done at 30 days after transplanting. Irrigation was given just after transplanting and later on watering was done at seven day's interval. Foliar spray of zinc sulphate, ferrous sulphate and borax (each 3 g) was given at 30 and 45 days after transplanting. Monitoring and field visits were conducted regularly to collect feedback and provide solutions to the problems reported by the participating farmers. All the observations were recorded on randomly selected twenty five plants, except the yield (t/ha), which was computed based on the net plot yield.

\section{Statistical analysis}

Statistical analysis was performed as per methods suggested by Panse and Sukhatme (1985).

\section{Results and Discussion}

In Vadavathur village of Namakkal District, Tamil Nadu community small onion nursery with low seed rate and drought tolerant variety $\mathrm{Co}(\mathrm{on}) 5$ was taken up on $1^{\text {st }}$ October $\left(1^{\text {st }}\right.$ nursery $), 15^{\text {th }}$ October $\left(2^{\text {nd }}\right.$ nursery $) \& 1^{\text {st }}$ November ( $3^{\text {rd }}$ nursery), respectively each in 5 farmers fields. During 2011 and 2012 Rabi season, KVK, Namakkal implemented this strategy and demonstrated the concept of community small onion nursery in Vadavthur village. 21 numbers of farmers adopted this technique and jointly produced seedlings to ensure timely transplanting of correct age seedlings for higher productivity and reduce the risk associated with deficit/delayed onset of monsoon. In 2012-13, this village experienced deficit rainfall situation in November and December. During Rabi 2013, 2014 and 2015 small onion nurseries were taken up by the community with staggered sowings on $1^{\text {st }}$ October and $15^{\text {th }}$ October could be used for transplanting in November after receipt of rain in an area of 20 ha. In $2014-15$ and $2015-16$, Community nursery was demonstrated on 0.4 ha covering 20 farmers. Majority of the farmers could take up transplanting using seedlings from the $1^{\text {st }}$ and $2^{\text {nd }}$ nursery raised on $1^{\text {st }}$ and $15^{\text {th }}$ October.

\section{Growth parameters}

Seedling height at 40 days after sowing was significantly influenced by climatic conditions prevailed in the particular region. Irrespective of the sowing time, it is explicit 
from the perusal of the Table 3 , that the seedling height $(17.4 \mathrm{~cm})$, leaf sheath diameter $(1.01 \mathrm{~cm})$, number of leaf sheath (2.82), No. of roots (15.4) and root length $(5.06 \mathrm{~cm})$ of was recorded as growth parameters in small onion variety $\mathrm{Co}(\mathrm{On}) 5$ at 40 days after sowing. This might be due to optimum soil temperature, relative humidity and rainfall prevailed during the growth period of small onion variety Co (On)5. The results are in accordance with finding of Jilani (2004).

\section{Bulb characters of small onion}

It was obvious from the data presented in Table 4 indicate that the maximum equatorial diameter of compound bulb $(5.02 \mathrm{~cm})$, polar diameter of the compound bulb $(4.69 \mathrm{~cm})$ and weight of the compound bulb (19.9 gram) was recorded in Co (On) 5 variety when compared to Co4 variety, which recorded $4.29 \mathrm{~cm}, 3.91$ $\mathrm{cm}$ and 8.76 gram respectively. In the present study the bulbs which were directly planted during December were subjected to initial mild temperature of $22.71^{\circ} \mathrm{C}$ and when they entered the bulbing phase the temperature rose up to $31.07^{\circ} \mathrm{C}$ and there was further increase as the bulbs had been maturing. Low night temperature and high day temperature induced more bulb yield in December transplanted seedling. Mohanty (2002) have reported high bulb yield in early planting depending upon the location of experiment. It might be due to better source sink relationship and higher photosynthetic activity which would have improved due to timely availability of nutrients through applied nutrients by soil as well as foliar application hence, better harvest of sunlight. Similar results have been reported by Rohini and Paramaguru (2017) (Table 5).

Table.1 Rainfall data of NICRA village during Small onion cropping season from 2011 - 2015

\begin{tabular}{|c|c|c|c|c|c|c|c|}
\hline Sl.No & Year & November & December & January & February & $\begin{array}{c}\text { Rainy } \\
\text { days }\end{array}$ & $\begin{array}{c}\text { Total rainfall } \\
(\mathbf{m m})\end{array}$ \\
\hline $\mathbf{1 .}$ & 2011 & $95 \mathrm{~mm}$ & $19 \mathrm{~mm}$ & $1 \mathrm{~mm}$ & 0 & 9 & $115 \mathrm{~mm}$ \\
\hline $\mathbf{2 .}$ & 2012 & $2 \mathrm{~mm}$ & 0 & 0 & $38 \mathrm{~mm}$ & 2 & $40 \mathrm{~mm}$ \\
\hline $\mathbf{3 .}$ & 2013 & $61 \mathrm{~mm}$ & $38 \mathrm{~mm}$ & 0 & 0 & 5 & $99 \mathrm{~mm}$ \\
\hline $\mathbf{4 .}$ & 2014 & $69 \mathrm{~mm}$ & $61 \mathrm{~mm}$ & 0 & 0 & 7 & $130 \mathrm{~mm}$ \\
\hline $\mathbf{5 .}$ & 2015 & $100.5 \mathrm{~mm}$ & 0 & 0 & 0 & 8 & $100.5 \mathrm{~mm}$ \\
\hline
\end{tabular}

Table.2 Dry spells (in days) during cropping period from 2011 to 2015 at Vadavathur

\begin{tabular}{|l|c|c|c|c|c|}
\hline Particulars & Year & \multicolumn{4}{|c|}{ Month (Cropping period) } \\
\cline { 3 - 6 } & & November & December & January & February \\
\hline \multirow{2}{*}{$\begin{array}{l}\text { Duration } \\
\text { of dry spell }\end{array}$} & 2011 & 16 & 25 & 31 & 29 \\
\cline { 2 - 6 } & 2012 & 30 & 31 & 31 & 14 \\
\cline { 2 - 6 } & 2013 & 17 & 19 & 31 & 28 \\
\cline { 2 - 6 } & 2014 & 18 & 27 & 31 & 29 \\
\cline { 2 - 6 } & 2015 & 2 & 31 & Vowing - & Vegetative \\
Crop stage & & $\begin{array}{c}\text { Sowing of onion } \\
\text { bulbs. }\end{array}$ & $\begin{array}{c}\text { Bulbing } \\
\text { stage }\end{array}$ \\
\hline
\end{tabular}


Table.3 Growth parameter of small onion var.Co(On)5

\begin{tabular}{|c|c|c|c|c|c|}
\hline $\begin{array}{c}\text { Field } \\
\text { number }\end{array}$ & $\begin{array}{c}\text { Seedling } \\
\text { height }(\mathbf{c m})\end{array}$ & $\begin{array}{l}\text { Leaf } \\
\text { diameter }\end{array} \mathbf{( c m )}$ & $\begin{array}{l}\text { Nheath } \\
\text { Number } \\
\text { leaf sheath }\end{array}$ & $\begin{array}{l}\text { No. } \\
\text { roots }\end{array}$ & Root length (cm) \\
\hline $\mathbf{1}$ & 14.83 & 0.93 & 2.67 & 13.00 & 3.20 \\
\hline $\mathbf{2}$ & 17.97 & 0.83 & 2.67 & 15.67 & 4.37 \\
\hline $\mathbf{3}$ & 20.00 & 0.93 & 2.67 & 17.00 & 6.80 \\
\hline $\mathbf{4}$ & 15.30 & 1.07 & 3.00 & 14.67 & 4.90 \\
\hline $\mathbf{5}$ & 17.23 & 0.83 & 3.00 & 17.67 & 4.50 \\
\hline $\mathbf{6}$ & 15.30 & 0.93 & 3.00 & 15.00 & 6.83 \\
\hline $\mathbf{7}$ & 16.40 & 1.00 & 2.67 & 15.67 & 3.67 \\
\hline $\mathbf{8}$ & 18.57 & 1.17 & 3.33 & 13.33 & 4.97 \\
\hline $\mathbf{9}$ & 17.87 & 0.90 & 2.67 & 15.00 & 4.73 \\
\hline $\mathbf{1 0}$ & 18.10 & 0.90 & 3.00 & 18.00 & 6.17 \\
\hline $\mathbf{1 1}$ & 17.67 & 0.90 & 2.67 & 16.00 & 5.53 \\
\hline $\mathbf{1 2}$ & 17.23 & 0.97 & 2.67 & 17.33 & 5.17 \\
\hline $\mathbf{1 3}$ & 19.40 & 1.30 & 2.67 & 15.67 & 5.37 \\
\hline $\mathbf{1 4}$ & 17.13 & 1.30 & 3.00 & 14.33 & 4.90 \\
\hline $\mathbf{1 5}$ & 18.00 & 1.13 & 2.67 & 13.00 & 4.77 \\
\hline Mean & $\mathbf{1 7 . 4}$ & $\mathbf{1 . 0 1}$ & $\mathbf{2 . 8 2}$ & $\mathbf{1 5 . 4}$ & $\mathbf{5 . 0 6}$ \\
\hline SED & 2.29 & 0.24 & 0.43 & 1.74 & 1.09 \\
\hline CD(p=05) & 4.71 & 0.48 & 0.88 & 3.57 & 2.24 \\
\hline
\end{tabular}

Table.4 Bulb characters of small onion variety Co4 vs Co (On) 5

\begin{tabular}{|c|c|c|c|c|c|c|}
\hline \multirow[t]{2}{*}{$\begin{array}{l}\text { Field } \\
\text { Number }\end{array}$} & \multicolumn{2}{|c|}{$\begin{array}{l}\text { Equatorial diameter of } \\
\text { compound bulb }(\mathrm{cm})\end{array}$} & \multicolumn{2}{|c|}{$\begin{array}{l}\text { Polar diameter of } \\
\text { compound bulb }(\mathrm{cm})\end{array}$} & \multicolumn{2}{|c|}{$\begin{array}{l}\text { Weight of the compound } \\
\text { bulb (g) }\end{array}$} \\
\hline & Co $(\mathrm{On}) 5$ & Co4 & Co $(\mathrm{On}) 5$ & Co4 & Co (On)5 & Co4 \\
\hline 1 & 4.93 & 4.47 & 4.40 & 3.86 & 18.93 & 8.17 \\
\hline 2 & 4.87 & 4.23 & 4.65 & 3.81 & 25.57 & 8.53 \\
\hline 3 & 5.27 & 4.30 & 4.94 & 3.96 & 16.30 & 8.73 \\
\hline 4 & 4.97 & 4.37 & 4.80 & 4.01 & 17.37 & 8.90 \\
\hline 5 & 5.03 & 4.27 & 4.78 & 3.96 & 16.67 & 8.63 \\
\hline 6 & 5.10 & 4.27 & 4.83 & 3.84 & 19.47 & 8.47 \\
\hline 7 & 4.93 & 4.30 & 4.59 & 3.85 & 20.37 & 8.57 \\
\hline 8 & 5.07 & 4.43 & 4.61 & 3.89 & 19.43 & 8.67 \\
\hline 9 & 4.83 & 4.17 & 4.71 & 4.01 & 20.20 & 8.67 \\
\hline 10 & 5.13 & 4.30 & 4.48 & 3.95 & 19.10 & 9.10 \\
\hline 11 & 5.03 & 4.33 & 4.67 & 3.83 & 20.23 & 9.17 \\
\hline 12 & 4.90 & 4.37 & 4.83 & 3.97 & 20.97 & 8.70 \\
\hline 13 & 5.23 & 4.30 & 4.66 & 4.00 & 22.30 & 8.77 \\
\hline 14 & 5.00 & 4.17 & 4.79 & 3.94 & 20.83 & 8.93 \\
\hline 15 & 5.00 & 4.13 & 4.70 & 3.91 & 21.07 & 9.40 \\
\hline Mean & 5.02 & 4.29 & 4.69 & 3.91 & 19.9 & 8.76 \\
\hline SED & 0.13 & 0.11 & 0.10 & 0.12 & 2.17 & 0.48 \\
\hline$C D(p=05)$ & 0.28 & 0.24 & 0.21 & 0.25 & 4.46 & 0.98 \\
\hline
\end{tabular}


Table.5 Yield parameters of small onion var.Co4 vs $\mathrm{Co}(\mathrm{On}) 5$

\begin{tabular}{|c|c|c|c|c|c|c|}
\hline \multirow{2}{*}{$\begin{array}{c}\text { Field } \\
\text { Number }\end{array}$} & \multicolumn{2}{|c|}{ No.of compound bulb / kg } & \multicolumn{2}{|c|}{ No.of bulblets/kg } & \multicolumn{2}{c|}{ Yield / Plant (g) } \\
\hline $\mathbf{C o}(\mathbf{O n}) \mathbf{5}$ & $\mathbf{C o 4}$ & $\mathbf{C o}(\mathbf{O n}) \mathbf{5}$ & $\mathbf{C o 4}$ & $\mathbf{C o}(\mathbf{O n}) \mathbf{5}$ & $\mathbf{C o 4}$ \\
\hline $\mathbf{1}$ & 24.33 & 42.67 & 77.67 & 94.33 & 68.23 & 23.67 \\
\hline $\mathbf{2}$ & 24.00 & 43.00 & 78.33 & 91.00 & 72.97 & 23.33 \\
\hline $\mathbf{3}$ & 24.00 & 45.33 & 77.00 & 92.00 & 75.40 & 23.57 \\
\hline $\mathbf{4}$ & 23.00 & 44.67 & 76.33 & 89.00 & 74.33 & 22.13 \\
\hline $\mathbf{5}$ & 22.33 & 42.33 & 76.33 & 89.33 & 74.20 & 23.73 \\
\hline $\mathbf{6}$ & 23.00 & 45.67 & 76.67 & 89.33 & 75.97 & 23.10 \\
\hline $\mathbf{7}$ & 22.67 & 44.33 & 77.33 & 88.33 & 77.57 & 24.07 \\
\hline $\mathbf{8}$ & 25.00 & 43.33 & 78.33 & 89.33 & 76.77 & 24.33 \\
\hline $\mathbf{9}$ & 24.00 & 43.00 & 74.67 & 89.00 & 78.73 & 23.87 \\
\hline $\mathbf{1 0}$ & 24.33 & 44.00 & 73.67 & 89.33 & 77.00 & 25.43 \\
\hline $\mathbf{1 1}$ & 24.67 & 42.33 & 74.00 & 87.67 & 78.83 & 26.13 \\
\hline $\mathbf{1 2}$ & 25.33 & 42.67 & 73.67 & 87.00 & 80.50 & 25.33 \\
\hline $\mathbf{1 3}$ & 24.33 & 43.33 & 75.33 & 87.33 & 79.73 & 24.77 \\
\hline $\mathbf{1 4}$ & 24.67 & 44.33 & 73.67 & 87.33 & 82.93 & 26.33 \\
\hline $\mathbf{1 5}$ & 23.67 & 45.33 & 75.33 & 89.00 & 83.00 & 26.27 \\
\hline Mean & $\mathbf{2 3 . 9 5}$ & $\mathbf{4 3 . 7 5}$ & $\mathbf{7 5 . 8 8}$ & $\mathbf{8 9 . 2 8}$ & $\mathbf{7 7 . 0 7}$ & $\mathbf{2 4 . 4 0}$ \\
\hline SED & 1.38 & 1.51 & 2.10 & 2.35 & 4.66 & 2.25 \\
\hline CD (p= 05) & 2.84 & 3.10 & 4.31 & 4.82 & 9.56 & 4.62 \\
\hline & & & & & & \\
\hline
\end{tabular}

Fig.1 Total rainy days of Vadavathur village during onion cropping season

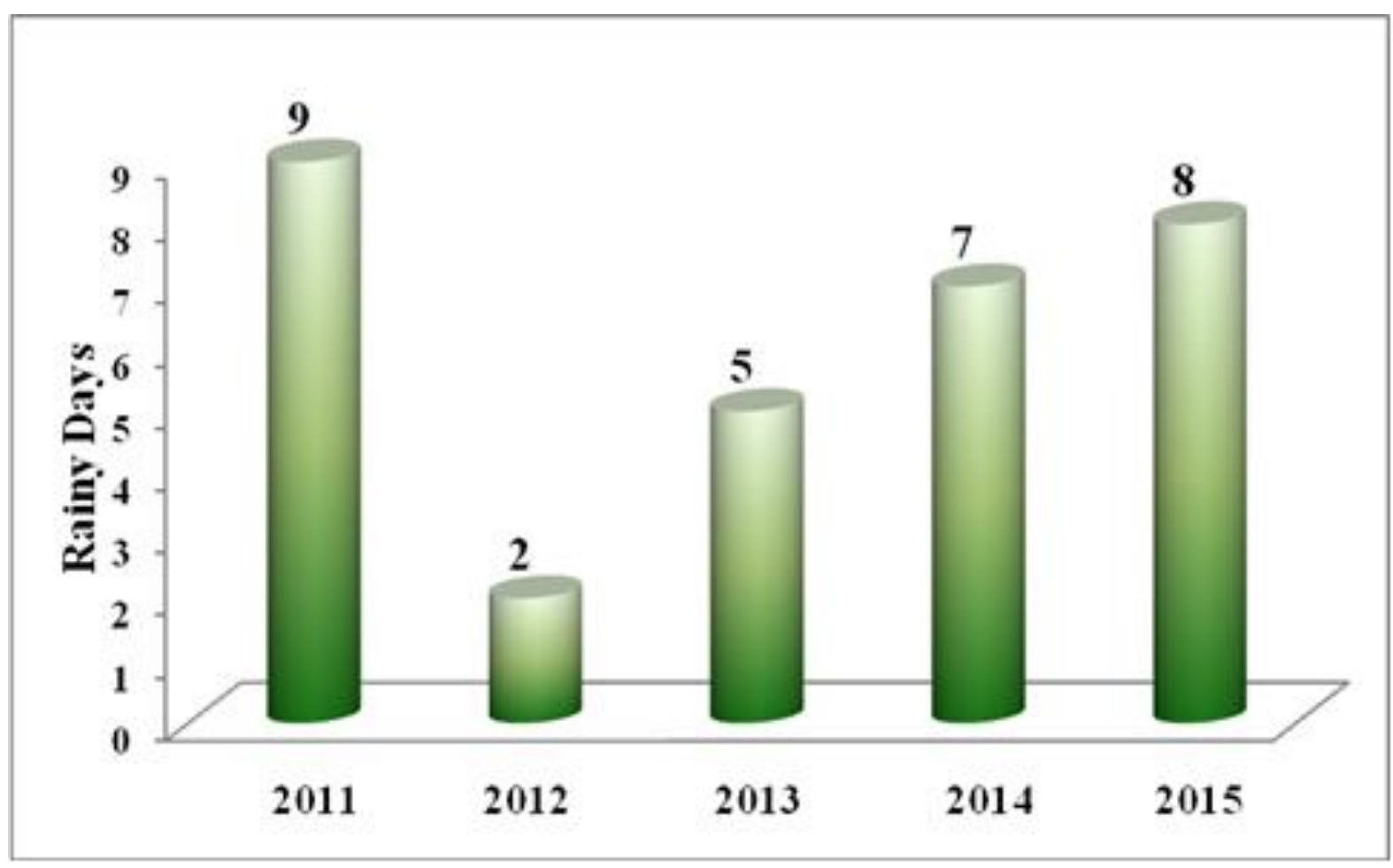


Fig.2 Total rainfall received at Vadavathur village during onion cropping season

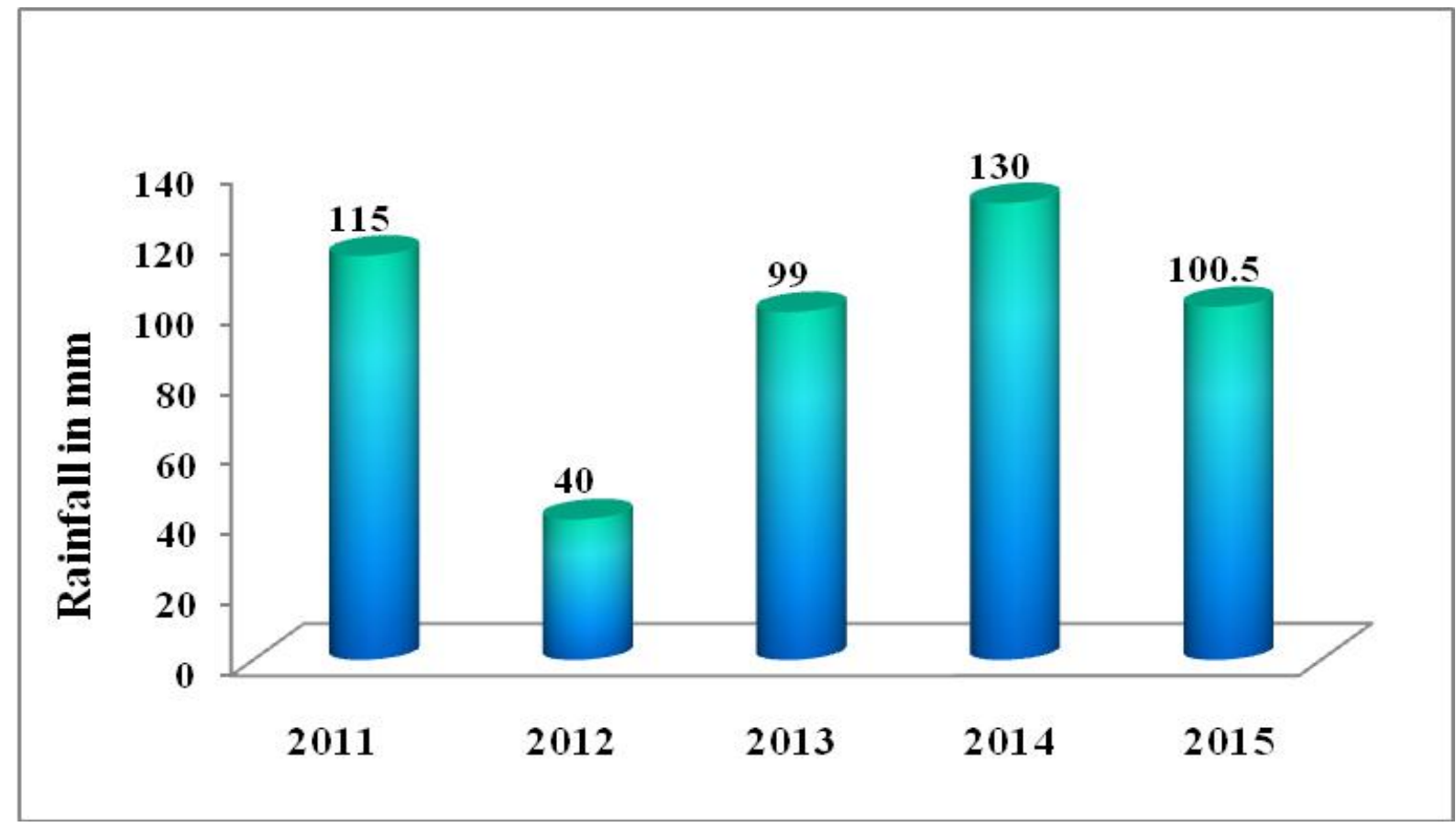

Fig.3 Total Rainfall and rainy days of Vadavthur village during onion cropping period from $2011-2015$

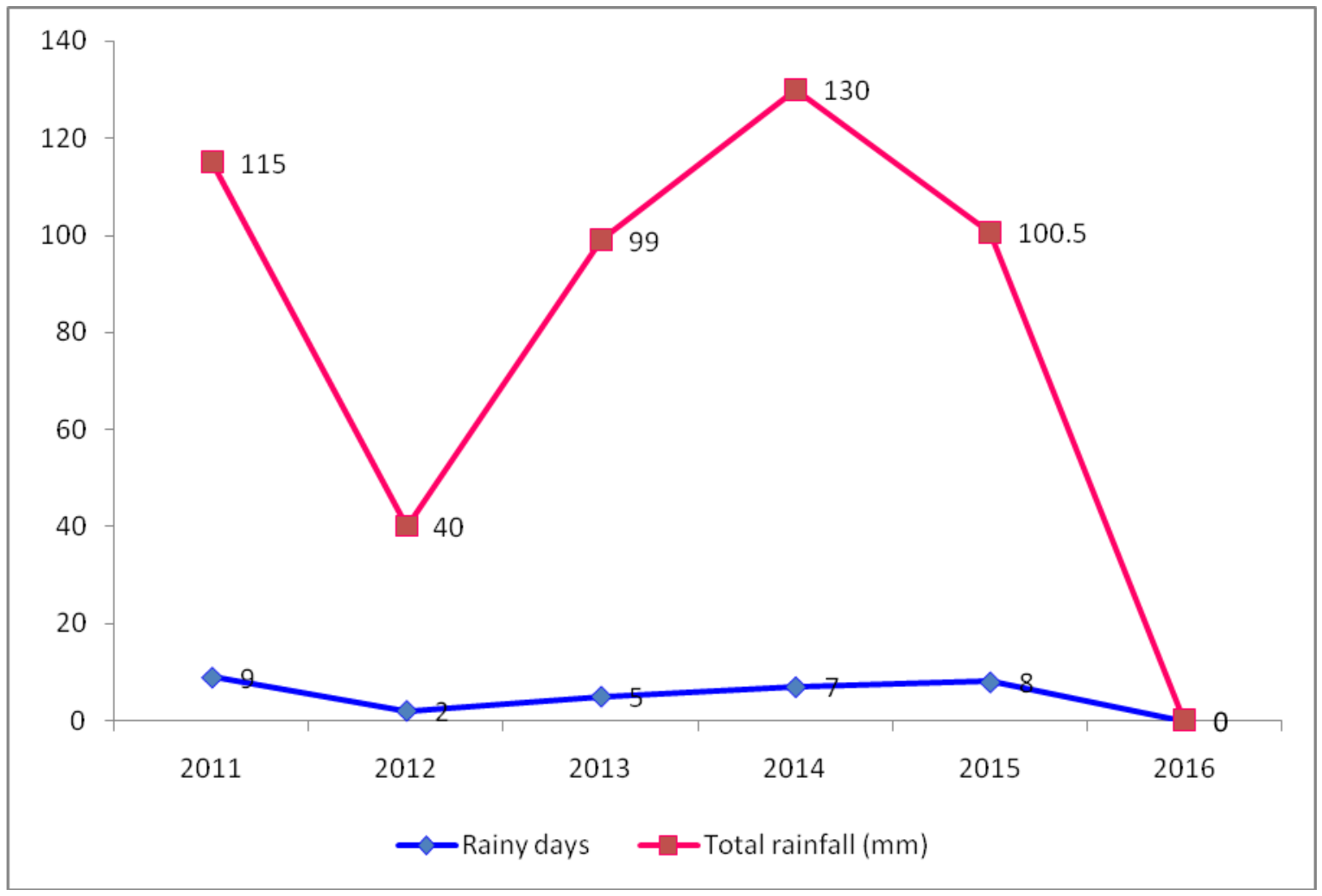




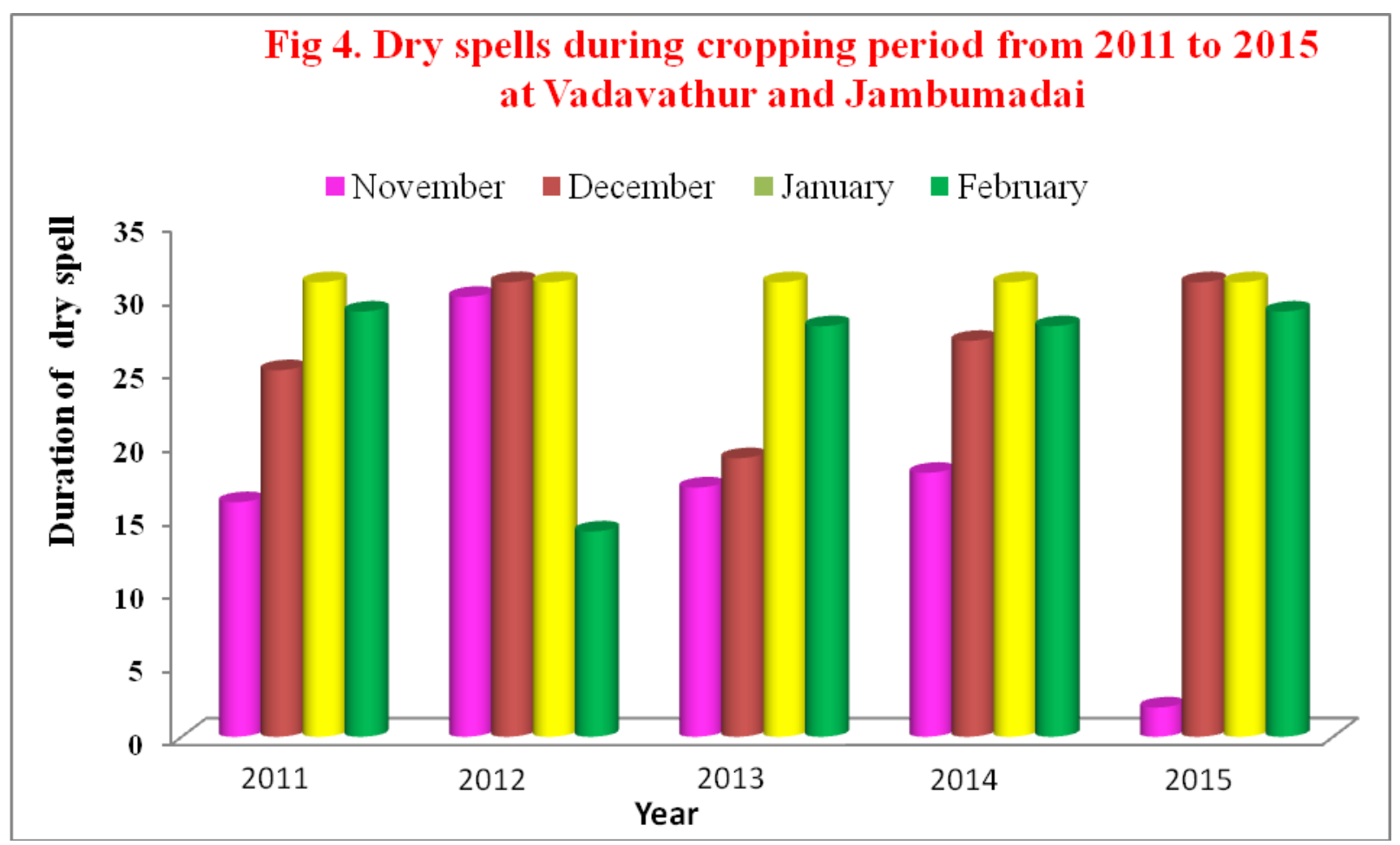

In addition to that application of micronutrients such as zinc and boron through soil or foliar or in combination had a beneficial effect on the growth of onion. This may be due to initial soil application and two foliar application of zinc sulphate.

Zinc is essential for tryptophan synthesis, which is a prerequisite for auxin formation, therefore amount of auxin decreases by zinc deficiency (Pedler et al., 2000; Marschner, 1995; Cakmak et al., 1989). This may be due to the improved growth characters as a result of foliar application of micronutrient which would have enhanced photosynthesis and other metabolic activities, which lead to increase in cell division and elongation (Hatwar et al., 2003). This result is in agreement with Schmidt (1964); Katare et al., (1971); Smriti et al., (2002); Manna (2013) in onion.

The bulb yield/ plant (77.07 gram) was recorded under the treatment combination small onion variety $\mathrm{Co}(\mathrm{On}) 5$ planted during $\mathrm{I}^{\mathrm{st}}$ week of November. The lowest bulb yield/plant (24.40 gram) was obtained under small onion variety Co 4 planted during $2^{\text {nd }}$ fortnight of December. The findings of Uddeen (2008) supported that increased yield may be because of difference in yield components as bulb volume, average weight of the bulbs and crop stand. Secondly it may be because of the seedlings planted early in the season getting established in field earlier. Consequently, early planting resulted in early continued swelling of the bulbs till the crop matured for harvesting. During late planting of Co4 variety of small onion the bulb size could not be developed which depended on temperature and day length. In this case the production assimilate would have been translocated towards developing sink (seeds) rather bulbs. In want of sufficient metabolites the bulbs remained underdeveloped.

The high yielding performance of onion variety Co (On) 5 at farmer's field was also reported by Umesh Acharaya et al (2015). Increase in bulb yield is mainly attributed to positive association between yield and yield contributing parameters like bulb weight and 
size in terms of equatorial and polar diameter of the bulb and also the better management of thrips in the onion field through barrier crops and blue sticky traps. Thrips are weak fliers and can be carried by wind. Therefore, planting live- barriers like maize could effectively block adult thrips from reaching onion plants. Two rows of maize surrounding onion field blocks adult thrips up to 80 per cent and blue sticky traps attracted the thrips in the inside field up to 90 per cent (Srinivas and Lawande, 2006). This practice brings down insecticide application.

\section{Extent of adoption and impact}

These farmers' benefitted with an additional yield of 1.8 to 2 tonnes / ha ( $25 \%$ increase in yield) compared to farmers who directly sown bulbs during December.

In Namakkal, State Department of Horticulture, Erumapatti block has supplied small onion var.Co(On) 5 seed under $50 \%$ subsidy to NICRA village farmers for promoting farmer managed community nurseries under assured irrigation to make available onion seedlings for transplanting to meet contingent situations. Under this scheme, a community nursery in an area of 0.8 ha was raised and the seedlings were transplanted in 20 acres in 20 farmer's field in Vadavthur village.

\section{Economics}

The total cost of cultivation ranged from Rs.78,000 to Rs.87,306 / ha. Bulb yield obtained was in the range of $250-275$ bags/ ha $(@ 81 \mathrm{~kg} / \mathrm{bag}=20.2$ tonnes to 22.3 tonnes/ha) using 40 days old small onion seedlings of $\mathrm{Co}(\mathrm{On}) 5$ variety, which was raised in the month of $1^{\text {st }}$ week of October. Highest net returns of Rs.3,03,750/- and benefit cost ratio of 3.4 was obtained by transplanting of onion seedlings which coincides with rainy days during November.

\section{Upscaling}

Community nursery was demonstrated in 2.8 ha covering 120 farmers in an area of 52.8 ha from 2011 to 2015 in Vadavathur village. Individual farmers or farmers group belonging to NICRA village are motivated to raise the onion seedlings and make availability during rainy season. Success stories of community nurseries as a contingency for delayed planting was presented in Farmers Grievance day meeting at District Collectorate and exposure visit of farmers made from various NICRA KVKs and Other KVKs (Perambalur, Karur, Villupuram, Dharwad, Dindigul, Ramanathapuram, Mysore, Alleppey) also visited this resilient practice.

\section{Acknowledgement}

I would express my sincere gratitude to the officials of National Initiative on Climate Resilient Agriculture Scheme, CRIDA, Hyderabad, India who rendered financial as well as technical support towards implementation of climate resilient work at NICRA village of Namakkal District.

\section{References}

Anonymous 2014. State -wise estimates of area and production for onion in India. National Horticultural Board, Gurgaon, Haryana, India.

Cakmak I, Marschner H and Bangerth F.1989. Effect of zinc nutritional status on growth, protein metabolism and levels of indole-3-acetic acid and other photo hormones in bean (Phaseolus vulgaris). Journal of Experimental Botany 40: 405 - 412.

Jilani MS.2004. Studies on the management strategies for bulb and seed production of different cultivars of onion (Allium cepa L). MSc thesis, NWFP 
Agricultural University, Peshawar, Pakistan.

Hatwar GP, Gondane SU, Urkude SM and OV Gahukar. 2003. Effect of micronutrients on growth and yield of Chilli. J. Soil Crops 13: 123-125.

Katare DS, Kashyap RP and MP Singh.1971. Effect of potash and micronutrient spray on onion. Fert. News 16:51-52.

Manna D.2013. Growth, yield and bulb quality of onion (Allium cepa L.) in response to foliar application of boron and zinc. SAARC J. Agriculture 11: 149-153.

Marschner H.1995.Mineral nutrition of high plant. Academic Press: 330 -355.

Mohanty BK. 2002. Variability, heritability, interrelationship and path analysis in onion. Haryana Journal of Horticultural Sciences. 31(1-2): 84-87.

Panse KV and PV Sukhatme.1985. Statistical methods for agricultural workers. ICAR, New Delhi, India.

Pedler JF, Parker DR and DE Crowley. 2000. Zinc deficiency - induced phytosiderophore release by the Triticaceae is not consistently expressed in solution culture. Planta.211: 120-126.
Rohini N and P Paramaguru.2016. Seasons influence on bulb, seed yield and quality of aggregatum onion (Allium cepa var aggregatum). Int. J. Farm Sci., 6(1):174-183.

Saraswathi T, Sathiyamurthy VA, Tamilselvi NA and S. Harish.2017. Review on Aggregatum onion (Allium cepa L. var. aggregatum Don.). Int. J. Curr. Microbiol. App. Sci. 6(4):1649-1667.

Schmidt WA.1964. Influence of zinc on the performance of vegetables in Bajio Region Mexico. Pro.Reo.Amer. Soc. Hort. Sci. 7: 17-21.

Smriti S, Kumar R and SK Singh . 2002. Effect of sulphur and boron nutrition on growth, yield and quality of onion (Allium cepa L.). Journal of Applied Biology.12: 40-46.

Srinivas PS and Lawande. 2006. Maize barrier as a cultural method for the management of thrips in onion (Allium cepa L) Ind. J. Agril. Sci., 76:167 171.

Ud-deen MU.2008.Effect of mother bulb size and planting time on growth, bulb and seed yield of onion. Bangladesh Journal of Agricultural Research 33(3): 531-537.

\section{How to cite this article:}

Sharmila Bharathi, C. and Mohan, B. 2018. Community Small Onion/Multiplier Onion (Allium cepa var aggregatum) Nursery as a Contingency Measure for Delayed Planting in NICRA Village of Namakkal District, Tamil Nadu. Int.J.Curr.Microbiol.App.Sci. 7(03): 1974-1984. doi: https://doi.org/10.20546/ijcmas.2018.703.233 